\title{
Research on Development Status Quo and Issues of "Buyer System" Cross-border E-Commerce Platforms
}

\author{
Wan-ting Dong \\ Beijing Institute of Fashion Technology \\ Beijing, China \\ 315562391@qq.com
}

\author{
Lei Yao* \\ Beijing Institute of Fashion Technology \\ Beijing, China \\ sxyyl@bift.edu.cn
}

\begin{abstract}
As domestic consumers understood more about foreign commodities, more and more people became aware of the price differences home and abroad resulted from trade barrier, therefore a good development environment for domestic "buyer system" cross-border E-commerce came into being. This thesis mainly researches on the development status quo and issues of "buyer system" cross-border E-commerce platforms, and proposes relevant recommendations through sorting out issues of the corresponding platforms, which is significant to the development of "buyer system" cross-border E-commerce platforms.
\end{abstract}

Keywords-Buyer; Cross-border E-commerce; Platform

\section{INTRODUCTION}

Through researching on four typical "buyer system" crossborder E-commerce platforms, this thesis conducts contrastive analysis and comes to the following conclusions regarding issues of corresponding platforms: outstanding issues of knockoff and after-sale service on the platform for ymatou.com; knockoff issue for Gmall; lack of diversity for bolo.me; lack of product origin countries for Haojiemi.

Through sorting out the existing issues of four cases and meanwhile proposing corresponding solutions, with inferences drawn, the development status and existing issues of the entire "buyer system" cross-border E-commerce platforms can be inferred. Based on the entire industry, the overall recommendations are proposed as follows: "buyer" cross-border E-commerce platforms can attract customers by reducing or even eradicating knockoffs; we may increase logistics speed and ensure that the knockoff has no chance to mix in the logistics process; the platform shall attach great importance to after-sale service and make sure consumers are satisfied. The buyer involved in the dealing of knockoff shall be severely punished. We shall try all means to improve the customer experience.

It only took over twenty years for E-commerce in China to develop from booming phase to spurting phase. In 2013, the scale of B2B E-commerce trade worldwide even reached to 70 trillion USD, while the overall E-commerce market scale in our country amounted to 10.67 trillion Yuan. The highly strategically important E-commerce can efficiently facilitate the trade globalization and economic integration in our country. Buyer system originated from Europe in the 1960's, when the buyers travelling to various show fields around the world, knowing the newest trends and holding a big amount of orders were called "fashion sellers"[1]. Buyer system gradually became the mainstream of contemporary crossborder E-commerce. As the living standard and quality of Chinese citizens improves, people will prefer the shopping mode of buyer system, and thus accelerate the development of buyer system shopping platforms. This thesis happens to focus on the research on development status and issues of buyer system cross-border E-commerce platforms, provides reference for future theory and application, and thus is of utmost importance to the development of cross-border Ecommerce in China.

\section{ANALYSIS ON STATUS AND ISSUES OF "BUYER SYSTEM” CROSS-BORDER E-COMMERCE PLATFORMS}

\section{A. Reasons for Spurting Development and Status of "Buyer} System" Cross-border E-commerce

\section{1) Abundant user demand}

As people's living standards improved and the population of overseas experienced people increased, many domestic consumers became aware of the big price differences for Western brands between local markets and Chinese markets. However, four or five years ago, most consumers in China who were aware of the price differences were living in such first-tier cities as Beijing, Shanghai and Guangzhou. In third or fourth-tier cities, most consumers were not strongly aware of the price differences, mainly due to the delay of information transfer. Thanks to the popularization of the Internet in more coverage in China, the geographical boundaries against information transfer was broken and the efficiency of information transfer had a qualitative leap. By now, most middle-class consumers are aware that most brands from Europe, America, Japan and South Korea are much cheaper in their local markets than in Chinese markets. However, not all consumers have relatives or friends abroad who can buy for them when they plan to visit China [2]. So, many consumers opt to overseas buyers when they need to buy from abroad. An abundant user demand is therefore formed. 


\section{2) Bonus Policy}

The fast and good development of buyer platform crossborder E-commerce relies on the support of state policy. In recent years, the development of China's traditional foreign trade industry gradually slowed down, while cross-border Ecommerce demonstrated an excellent development trend. In recent years, China kept introducing new policies in favor of the development of cross-border E-commerce. With this convoy, the development of cross-border E-commerce kept stepping into new phases.

A typical example is: in July 2014, General Administration of Customs issued "Document No. 56"-Announcement on Supervision on Import and Export Commodities and Goods of Cross-border E-commerce. From the perspective of import buyer platform cross-border E- commerce, this would bring an impact on small companies which engaged in "grey zone purchasing" as it will apply tax collection and exemption as per general trade. This document concluded the pilot operation of cross-border E-commerce in China for the past several years, specifically affirming the legitimate status of cross-border E-commerce in China, effectively boosting the thriving of cross-border E-commerce in China and bringing new opportunities to cross-border Ecommerce platforms in China. It will successively bring a sophisticated and scientific supervision system.

\section{B. Contrastive Analysis of Typical "Buyer System” Cross- border E-commerce Platforms}

TABLE I CONTRASTIVE ANALYSIS OF FOUR MAJOR BUYER SYSTEM CROSS-BORDER E-COMMERCE PLATFORMS

\begin{tabular}{|c|c|c|c|c|}
\hline $\begin{array}{l}\text { Rlatform } \\
\text { Contrastive } \\
\text { Item }\end{array}$ & Ymatou.com & Gmall & Bolo.me & Haojiemi \\
\hline $\begin{array}{ll}\text { Year } & \text { of } \\
\text { establishment }\end{array}$ & 2009 & 2007 & 2015 & 2014 \\
\hline Mode of logistics & YMT GLOBAL INC & $\begin{array}{l}\text { Third-party logistics } \\
\text { platform }\end{array}$ & $\begin{array}{l}\text { Third-party logistics } \\
\text { platform }\end{array}$ & JMD Express \\
\hline Type of commodities & $\begin{array}{l}\text { Mainly apparel, } \\
\text { cosmetics, maternal and } \\
\text { infant supplies }\end{array}$ & All-inclusive & $\begin{array}{l}\text { Mainly female customer- } \\
\text { targeted cosmetics and } \\
\text { apparel }\end{array}$ & $\begin{array}{l}\text { Mainly } \\
\text { cosmetics }\end{array}$ \\
\hline Countries covered & $\begin{array}{l}\text { Mainly European and } \\
\text { American countries and } \\
\text { a big number of } \\
\text { countries }\end{array}$ & $\begin{array}{l}\text { Globally covered } \\
\text { countries and a big } \\
\text { number of countries }\end{array}$ & $\begin{array}{l}\text { Mainly Japan and South } \\
\text { Korea }\end{array}$ & $\begin{array}{l}\text { Mainly European and } \\
\text { American countries }\end{array}$ \\
\hline $\begin{array}{l}\text { Major payment } \\
\text { method }\end{array}$ & Alipay & Alipay & Alipay & Alipay \\
\hline Type of platform & Website and APP & Website and APP & APP & APP \\
\hline Type of price & $\begin{array}{l}\text { Mainly luxury brands of } \\
\text { apparel and cosmetics, } \\
\text { price ranging from } \\
\text { hundreds to tens of } \\
\text { thousand Yuan }\end{array}$ & $\begin{array}{l}\text { Big price range, } \\
\text { relatively fewer } \\
\text { expensive items in } \\
\text { luxury category }\end{array}$ & $\begin{array}{l}\text { Mainly "only selling for } \\
\text { local price", prices } \\
\text { ranging wide as per } \\
\text { different areas }\end{array}$ & $\begin{array}{l}\text { Mainly overseas } \\
\text { cosmetics, price ranging } \\
\text { from tens to tens of } \\
\text { thousand Yuan, mainly } \\
\text { discount prices for big } \\
\text { brands }\end{array}$ \\
\hline Major characteristics & $\begin{array}{l}\text { Self-built } \\
\text { many } \\
\text { warehouses }\end{array}$ & $\begin{array}{l}\text { Full categories and } \\
\text { types }\end{array}$ & $\begin{array}{l}\text { "only sell for local price": } \\
\text { "live streaming shopping" }\end{array}$ & $\begin{array}{l}\text { Strong team, abundant } \\
\text { financing from earlier } \\
\text { stage }\end{array}$ \\
\hline $\begin{array}{l}\text { Relative customer } \\
\text { satisfaction }\end{array}$ & Average & Average & Fairly good & Fairly good \\
\hline
\end{tabular}

This chapter has provided a detailed analysis of four "buyer" cross-border E-commerce platforms. So we get to know differences and problems concerning them. On contrast, main problems concerning them are summarized:

\section{1) Knockoff prevalence}

To look into the history of the "buyer" cross-border Ecommerce, you will find out that they were derived from the purchasing, which previously survived in the circle of friends. The cross-border E-commerce platform that thrives afterwards in essence provides a legitimate platform for the previous purchasing. In the meantime, it provides more channels for domestic consumers to access to foreign commodities. The previous purchasing survived because relevant national policies were not well-established. Thus, grey zone clearance purchasing had a space to live on. Even at present, there are no specific laws to determine the legitimateness of purchasing. Plentiful people were involved in the purchased. Till now, the majority of them have involved into the legal import E-commerce. By inheriting the 
previous purchasing mode, some law violators may get the legal platform for survival.

Another reason for the knockoff prevalence is that it's difficult for these four platforms to control the source of foreign supply chain. These four platforms mainly control Haitao data, with commodities and supply chain source overseas. It's difficult for these domestic "buyer" cross-border E-commerce platforms to effectively control the true origin of foreign commodities [3]. And even, some commodities are copycats that have been processed in China. After transfer several times, they are transferred to domestic consumers from overseas. It's impossible for the platform to identify authenticity and enable effective control, which on the other hand provides soil for the knockoff prevalence.

Thanks to the support by national policy in these two years, domestic development momentum of cross-border Ecommerce is very good. In the meantime, plenty of "buyer" cross-border E-commerce platforms thrive and rush for data instead of emphasizing supply chain input and development. Even if many platforms seem to have get substantive financing. The development mode of a platform in the beginning was very coarse. They mainly focus on seizing market users and devise many means to enhance sales revenue instead of emphasizing the supply chain development. Imperfect supply chain provides the space for the knockoff to get developed. It's impossible to get rid of knockoffs within the cross-border E-commerce community in a short period. However, if the whole industry attaches more importance to the supply chain input, we have a firm belief that the number of knockoff in the platform will greatly reduce. We are happy that some leading enterprises are beginning to resolve such issued. We hope that these leading enterprises can mobilize more cross-border E-commerce platform to work hard. Thus, the emphasis on the supply chain development will become an industry consensus. They take product quality as more important than their life, strive to conduct in-depth cooperation with the national quality supervision authority. We shall build for consumers an assured consumption environment and work hard to build a quality cross-border Ecommerce platform.

\section{2) Serious problems concerning logistics speed and cost}

Apart from very high logistics cost, it's not rare that the whole cross-border E-commerce platform is faced with a number of problems, including high unit transportation cost, slow delivery, damage and missing package. Such problems not only damage E-commerce earning, but also greatly affect consumers' shopping satisfaction. In terms of investment input, YMT GLOBAL INC of Ymatou.com has emerged as a pride among the cross-border E-commerce platforms [4].

There are many important reasons for steadfast logistics cost of cross-border E-commerce: according to the international logistics practice, the ratio of logistics cost to GDP may reflect the competitiveness of a national economics in the logistics industry. According to the report of CPAG Group [5], Chinese logistics cost in 2013 was 1.02 billion Yuan, accounting for $18 \%$ of the GDP, twice the figure in the U.S. In the meantime, it has exceeded that in such developing countries as India and Brazil, respectively at $13.0 \%$ and
$11.6 \%$. It indicates that the Chinese indicator not only clearly falls behind developed countries, which cannot even catch up with developing countries.

In recent years, Chinese government has intensified its efforts to develop infrastructure and achieved well-recognized results. It is natural such effort will help improve logistics service. Possibly, more enterprises shall focus on domestic logistics development, providing help for the development of logistics in their respective platform.

\section{3) Payment process safety has hazards}

Cross-border E-commerce is a new industry that just thrived. Usually, the issuance of national policy lags behind the development speed of a new industry. To give a most apparent example, small articles are exported without customs clearance, which seriously leads to the taxation issue. In several years in the past, foreign trade E-commerce vendors were even engaged in the "illegal private bank" to cope with the payment issue. All such moves have imposed grand risks on domestic consumers.

\section{4) After-sale service is not well-established}

Missing package during cross-border postage has been common. The claim period for consumers is very long so that domestic consumers have a very great psychological burden. Some consumers don't even dare to purchase. According to relevant report, in 2015, the Consumers Council handled 1,059 complaints associated with cross-border E-commerce, a growth of $368.6 \%$ than before. Among many categories, undoubtedly, beauty \& skin care, infant product and luggage are main consumption type. Complaints over these three types of commodities are very high, respectively accounting for $38 \%, 22 \%$ and $21 \%$ [6]. Besides, there are many special problems concerning the after-sale service: first, due to difference between policy home and abroad, the policy of "rejection without a reason within 7 days" is not tenable; second, commodity quantity standards for different countries have very big difference, and relevant production and consumption standards are varied, leading to difference of quality of finished product; third, it's difficult for buyers to be entitled to the after-sale service, and some foreign vendors don't provide or only provide very short-term maintenance service; fourth, it costs consumers a lot to safeguard their rights and interests because of commodity return expenses, taxation loss, time and energy spent .

This chapter has provided a detailed analysis of four "buyer" cross-border E-commerce platforms. So we get to know differences concerning them and their separate feature. On contrast, we draw conclusions below: Ymatou.com boasts of good financing, more capital and its self-built has a great advantage. However, logistics and cross-border E-commerce platform are simultaneously developed. Because of bigger capital and energy ratio, many details are not thoroughly considered, e.g. avoidance on knockoff; relying on the Taobao data, Gmall has all along enjoyed a good development momentum. Because of the most comprehensive product category, it still faces the problem of consumers' trust and knockoff; Bolo [4]. Me focuses on "only sell for local price" and "live streaming shopping", attracting many faithful consumers; Haojiemi relies on powerful startup team and 
impressive earlier financing and brand discount zone to attract more consumers. However, the whole team was just developed. In the cross-border E-commerce cluster era, it shall try hard to grab more market share.

\section{III. "BUYER” CROSS-BORDER E-COMMERCE PLATFORM DEVELOPMENT COUNTERMEASURES RECOMMENDATION}

\section{A. Overall Recommendation}

Individual buyers in $\mathrm{C} 2 \mathrm{C}$ cross-border E-commerce platform are not in the same level with such large Internet enterprise as JD in terms of fund, corporate management and marketing budget. However, the author's attitude towards small business startups remains unchanged: "small as the sparrow is, it possesses all its internal organs". The business of individual buyer seems to be quite easy, it involves all aspects of corporate operation, ranging from commodity procurement, pricing, logistics management, customer service, consumer behavior analysis and foreign exchange management. Each small link requires fine management. We shall learn to truly meet with consumers' demands, resolve their aching point and create an unprecedented value.

\section{1) Recommendation on knockoff}

"Knockoff incident" mostly comes from the transfer during the logistics transfer. It reflects in a certain way the complexity of the source of the cross-border E-commerce cargos. On one hand, we shall strengthen control over the source buyer and examinations on the qualification of buyer. We shall secure from the source that commodities purchased by consumers are original. On the other hand, we shall enhance logistics supply chain management. We shall send people to track the cargo and ensure that the commodities en route are always closed. We shall ensure legitimate clearance and real-time enquiry. Bolo. me (a typical cross-border Ecommerce advocating video live streaming) did well in this regard. I hope that other cross-border E-commerce platforms may learn from it.

We shall provide control over qualifications of platform buyer so that true buyer can provide original product for consumers. We shall learn from Ymatou.com with respect to the self-built logistics to ensure original product in the whole logistics process. In the meantime, we may provide one-stop logistics service and offer consumers a sense of commodity safety. We may also improve consumers' recognition and trust and cultivate faithful customers.

Individual buyers active in the "buyer" cross-border Ecommerce platform are mainly composed of full-time housewives, overseas students and Chinese and some parttime buyers. We may set up overseas operation team and use foreign staff for training on the platform buyer, introducing platform functions and helping the buyer to maintain the platform. With respect to SKU management, such platform shall provide guidance on the buyer so that more competent buyers will be introduced to the platform. We ensure simultaneous growth of platform and buyer. Competent buyer may also help secure improvement on product quality. With good revenue and business, most people are willing to conduct business.

\section{2) Recommendation on logistics speed and cost}

Compared with the traditional domestic E-commerce shopping, consumers of cross-border E-commerce platform shall wait for a very long period. Compared with domestic shopping, it takes longer time for the cargo to be available to consumers after going through supply chain system home and abroad. Therefore, consumers mainly choose the preferred cross-border E-commerce platform based on such indicators as the time needed for the cargo to be available to consumers or whether the platform can offer the commodities they want. According to the Report, overseas direct mail is popular among most consumers. The complexity of cross-border logistics makes many consumers unclear about how commodities are available to them. Besides, this form may help consumers to reduce the cost of Haitao. Thus, it has been favored by most consumers.

Duties and taxed are an important fiscal source of a country while the transaction of the "buyer" cross-border Ecommerce is largely a very big loophole for a country's fiscal revenue. The reform of the national taxation deals a heavy blow to the domestic cross-border E-commerce. However, it also makes the domestic cross-border E-commerce more standard.

The best mode of cross-border logistics at present is the overseas storage platform integrating provision of cargo origin, exhibition and promotion, storage circulation and after-sale service. It basically resolves problems associated with the cross-border E-commerce logistics, and emerges as a first choice of the cross-border E-commerce logistics development scheme.

With the issuance of relevant national management policy concerning the cross-border E-commerce platform, relevant enterprises from Zhejiang firsts enter the national trial. The responsible person of one enterprise says: "cross-border Ecommerce export product category has its scope expanded from small items as outfit into such big items as home furnishing and building material. Operation platform has turned from product sales to brand development. Cross-border export E-commerce has entered a brand-new development stage. Under such circumstance, overseas warehouse can better meet with the need of cross-border E-commerce enterprises, which has become an important link of overseas layout of the cross-border E-commerce”.

\section{3) Recommendation on payment process safety}

Supported by national policy, domestic cross-border Ecommerce is developed in a fast manner. However, payment rate and safety have been ailments. Although it has been exposed under the media, there has not been a very good solution yet. With the increase of varied cross-border Ecommerce trials, we hope to find out a better solution so that consumers can be more rest assured during shopping.

4) Recommendation on underdeveloped after-sale service

According to relevant data released, Chinese consumers of buyer cross-border E-commerce platform are not satisfied with the customer service. On one hand, most consumers have little knowledge about foreign commodities, and their demand on customer service is bigger. On the other hand, although 
real-time logistics enquiry and after-sale product replacement are the last threshold for the consumer shopping, such threshold is of utmost importance. We shall set up domestic warehouse for cargo replacement and rejection and ensure rejection without a reason in seven days.

With respect to the after-sale service, cross-border Ecommerce shall pay attention to eliminate knockoff. Varied "buyer" cross-border E-commerce platform and relevant national test authority shall arrive at the deep cooperation consensus [7]. Consumers shall be met with in terms of product testing, commodities recall and setup of refunding mechanism. Besides, statement shall be provided in the platform. Once consumers feel that commodities may be fake, the vendor shall arrange for testing. Once it's determined to be fake, the corresponding consumer may get compensation 10 times the product cost without providing evidence. The platform shall provide guarantee so that consumers can buy with assurance.

\section{B. Recommendations on Four Typical "Buyer" Platforms}

\section{1) Ymatou.com}

We shall pay attention to knockoff in the platform by attaching importance to the buyer certification. The self-built logistics of Ymatou Platform has many advantages. We shall pay attention to the capital application. It takes plenty of money to develop the self-built storage o YMT GLOBAL INC of Ymatou.com, and continuous long-term support of fund chain is required. In terms of after-sale service, we shall provide more service staff. We may try to introduce the mode of rejection without a reason in seven days. Besides, we shall try to increase the consumers' repurchase rate.

\section{2) Gmall}

We shall try to resolve the problem of knockoff product. Based on the original operation state of Taibao and impression remained in vast consumers, Gmall shall spend great efforts to change consumers' intrinsic mindset and strive to reduce the Taobao's negative influence on the Gmall. We shall strive to take advantage of vast consumer based in Taobao. We may take some similar measures as "live streamline shopping" to reduce the number of knockoff. Once that is done, Gmall may thus attract more consumers. It will thus enhance consumers' recognition on original product in the platform.

\section{3) Bolo.me}

With its emphasis on the product authenticity, Bolo.me stands out in a good image among many "buyer" cross-border E-commerce platforms. Because the platform just starts up, commodities are not so diverse, which can not be compared to those on many veteran cross-border E-commerce platforms. Therefore, Bolo.me shall focus on introducing more diverse products. It may thus retain more users by meeting with their needs in many aspects. We shall enhance the national presence of commodities and product type. We can take some publicity measures such as introducing Baidu Promotion to enhance reputation. Besides, we may develop the webpagebased platform, favorable for viewing by consumers.

\section{4) Haojiemi}

It boasts a good team, but its size is small. For its late startup, it cannot get much share among the "buyer" crossborder E-commerce market with fierce competition. Besides, it will be very difficult to win customers from such veteran platforms as Ymatou.com and Gmall. Thus, the platform operator shall emphasize on the quantity and quality of the operation team, detect business opportunities and win customers. We shall expand type of commodities and presence. We may develop the webpage-based platform favorable for viewing by consumers. We can do some advertising to enhance publicity.

\section{CONCLUSIONS}

By analyzing four typical "buyer" cross-border Ecommerce platforms and the prevailing national policy's influence on the cross-border E-commerce:

"Buyer" cross-border E-commerce platform mainly runs in forms of APP and website. We introduce overseas buyer to pick up product for domestic consumers. The majority of such platforms undergo settlement via Alipay. The majority of cross-border transportation will be done via the third-party logistics platform. Only very rare platform with more funds will set up logistics platform on their own. Such after-sale service as cargo rejection and replacement might not be so ideal because of cross-border customs clearance.

By studying cases, we may find out that such platforms have four problems: serious knockoff issue; the platform doesn't attach more importance to the logistics optimization. It thus leads to higher logistics cost and slower logistics speed. Consumers are not so satisfied with the logistics, which seriously affects the consumers' subjective impression with the platform; the platform mainly adopts online payment instead of credit card, and consumers thus face bigger payment risks; the platform's after-sale service "localization" is low. It takes a long time, and cost arising out of product rejection and replacement is high.

We may provide target-specific improvement comments based on summarizing problems arising out of the "buyer" cross-border E-commerce platform; Ymatou mainly improves after-sale service and eliminate knockoff by imposing buyer certification and logistics "localization"; Gmall mainly introduces more competent buyers to reduce number of knockoffs in the platform; Bolo.me gradually grows by providing more diverse products; Haojiemi attempts to attract more consumers by expanding the place of origin of commodities.

By analyzing cases and summarizing relevant problems and corresponding recommendation, we can provide some suggestions on the whole "buyer" cross-border E-commerce; "buyer" cross-border E-commerce platform may attract customers by reducing or even eradicating knockoffs; besides, we may increase logistics speed and ensure that the knockoff has no chance to mix in the logistics process; the platform shall attach great importance to after-sale service and make sure consumers are satisfied. The buyer involved in the 
dealing of knockoff shall be severely punished. We shall try all means to improve the customer experience.

\section{ACKNOWLEDGEMENT}

1) Beijing Excellent Talents Cultivating Funding Projects "Research on the optimization path of Beijing garment industry structure under the coordinated development of Beijing Tianjin Hebei” (Fund code: TSJH201510012002)

2) Beijing Excellent Talents Cultivating Funding Projects (Fund Code: 2014000026833ZS06)

3) The key project of social science program for Beijing Municipal Education Commission 2016(SZ201610011208)

\section{REFERENCES}

[1] Lai,K.E-business and Export Behaviour Evidence from Indian Firms [J],World Development,2004,3(32):505-517.

[2] TANG Bingyong, Xiong Li. Chinese Cross-border E-commerce Development Report (2015-2016) [M]. Beijing: Chemical Industry Press, 2016:48.

[3] XU Mengmeng. Research on Development Status Quo and Issues of Chinese Cross-border E-commerce [D]. Anhui: Anhui University, 2016.

[4] LI Pengbo, Ma Feng. Import Cross-border E-commerce Revelations [M]. Beijing: Publishing House of Electronics Industry, 2016:56.

[5] Ymatou. Website Profile [N/OL]. Official Website of Ymatou, 200904-12(7)[2017-03-06].http://about.ymatou.com/.

[6] HE Li. When the Monk Comes Across Cross-border E-commerce [M]. Beijing: Publishing House of Electronics Industry, 2016:25.

[7] YU Guilan. Under Cross-border E-commerce B2C Platform: Trade Disputes Processing Rules and Related Process-Take AliExpress Online Trade Dispute Rules (English) as an Example [J]. Practice in Foreign Economic Relations and Trade, 2016,(09):48-51. 